\title{
PENGARUH MODEL PROBLEM BASED LEARNING TERHADAP KETERAMPILAN BERPIKIR KRITIS SISWA KELAS VII SMP PADA PEMBELAJARAN IPA
}

\author{
Iluh Via Vanellia Darma, I Nyoman Suardana, Kompyang Selamet \\ Program Studi S1 Pendidikan IPA \\ Universitas Pendidikan Ganesha \\ Singaraja, Indonesia \\ e-mail: \{vanellia.darma@undiksha.ac.id,nyoman.suardana@undiksha.ac.id, \\ kompyang.selamet@undiksha.ac.id \}
}

\begin{abstract}
Abstrak
Penelitian ini bertujuan menganalisis perbedaan keterampilan berpikir kritis antara siswa yang dibelajarkan dengan model problem based learning (PBL) dan model pembelajaran kooperatif tipe student team achievement division (STAD). Penelitian ini merupakan penelitian eksperimen semu dengan rancangan nonequivalent pretestposttest control group design. Populasi penelitian adalah seluruh siswa kelas VII SMP Negeri 6 Singaraja tahun ajaran 2017/2018 yang berjumlah 304 orang yang tersebar ke dalam 11 kelas. Sampel penelitian berjumlah 50 siswa yang diambil dengan teknik cluster random sampling, yaitu siswa kelas VIIB 3 sebagai kelas eksperimen yang diberikan perlakuan model PBL dan siswa kelas VIIB 4 sebagai kelas kontrol yang diberikan perlakuan model kooperatif tipe STAD. Objek penelitian adalah keterampilan berpikir kritis siswa. Data keterampilan berpikir kritis siswa diperoleh dengan metode tes dan dianalisis dengan analisis deskriptif dan analisis ANAKOVA satu jalur dengan taraf signifikansi 5\%. Hasil penelitian menunjukan keterampilan berpikir kritis siswa yang dibelajarkan dengan model PBL lebih baik dibandingkan dengan siswa yang dibelajarkan dengan model pembelajaran kooperatif tipe STAD. Nilai rata-rata posttest siswa kelas eksperimen dan kelas kontrol berturut-turut sebesar 73,73 dan 68,93.
\end{abstract}

Kata kunci: model problem based learning, model pembelajaran kooperatif tipe student team achievement division, keterampilan berpikir kritis

\begin{abstract}
This study was aimed to analyze differences critical thinking skill between students taught using problem based learning model and cooperative learning model type student team achievement division (STAD). This study belongs to quasi experimental and used nonequivalent pretestposttest control group design. The population of study is all students of VII of SMP Negeri 6 Singaraja academic year 2017/2018 which amounted to 304 people divided into 11 groups. The sample of this research is 50 students taken by cluster random sampling technique, that is group VIIB 3 students as experiment group given treatment of problem based learning model and grade VIIB 4 students as control group given cooperative learning model type STAD treatment. Meanwhile, the objects of the study were critical thinking skill. The data of critial thinking skill obtained by test method and analyzed by using descriptive analysis and one-way ANACOVA at the significant $5 \%$. The results showed students' critical thinking skills that were taught by PBL model better than the students who were taught by cooperative learning model type STAD. The average posttest value of the experiment group and the control group was 73,73 and 68,93, respectively.
\end{abstract}

Keywords: problem based learning model, cooperative learning model type student team achievement division, critical thinking skill 


\section{PENDAHULUAN}

Berpikir kritis telah menjadi suatu kebutuhan karena berbagai nilai strategis kemampuan berpikir tersebut dalam rangka memandirikan seseorang. Berpikir kritis dan keterampilan berpikir merupakan dua hal yang saling berhubungan. Berpikir kritis diartikan sebagai cara berpikir yang sistematis dan mandiri yang menghasilkan suatu interpretasi, analisis, kesimpulan terhadap sesuatu, evaluasi, dan memberi penjelasan tentang sesuatu dan keterampilan berpikir merupakan alat dalam hidup jangka panjang (Tenggarudin, 2016)

Walker (dalam Redhana, 2012) menyatakan bahwa keterampilan berpikir kritis merupakan suatu proses yang memungkinkan siswa memperoleh pengetahuan baru melalui proses pemecahan masalah dan kolaborasi. Keterampilan berpikir kritis penting dalam proses pembelajaran karena keterampilan ini memberikan kesempatan kepada siswa belajar melalui penemuan (Redhana, 2012).

Berbagai upaya telah dilakukan oleh pemerintah untuk meningkatkan keterampilan berpikir kritis siswa di Indonesia, salah satunya adalah menerapkan kurikulum 2013. Salah satu keunggulan kurikulum ini, guru memeroleh kesempatan secara luas untuk mengembangkan kreativitas dan mengarahkan anak didik untuk melakukan, Observing (pengamatan), Questioning (bertanya), Associating (nalar), Experimenting (mencoba), dan Networking (membentuk Jaringan). Salah satu mata pelajaran yang penting dalam kurikulum 2013, yaitu ilmu pengetahuan alam (IPA). Guna mencapai tujuan pendidikan IPA dalam kurikulum 2013, pemerintah telah menerapkan standar pendidikan, tiga diantaranya yaitu standar isi, standar proses dan standar penilaian pendidikan. Idealnya pendidikan IPA dilaksanakan sesuai dengan standar yang telah ditetapkan oleh pemerintah, apabila hal ini sudah dilaksanakan dengan baik dan benar maka keterampilan berpikir kritis siswa di Indonesia juga akan baik. Fakta di lapangan menunjukan bahwa keterampilan berpikir kritis siswa di Indonesia masih rendah.

Fakta ini dibuktikan dengan hasil penelitian oleh IEA (International Association for the Evaluation of Educational Achievement) dalam event TIMSS (Trends in Mathematics and Science Study) yang diselenggarakan pada tahun 2011 dan 2015. Hasil penelitian TIMSS 2011 untuk bidang sains, Indonesia menempati peringkat ke36 dari total 42 negara. Tidak jauh berbeda, hasil penelitian TIMSS 2015 untuk bidang sains, Indonesia menempati peringkat 46 dari 51 negara dengan skor 397 lebih rendah dari skor rata-rata yaitu 500. Berdasarkan jumlah skor yang dicapai baik pada TIMSS 2011 maupun TIMSS 2015, Indonesia mendapat predikat low science benchmark. Predikat tersebut menyatakan bahwa siswa Indonesia hanya mampu mengenal sebagian fakta-fakta dasar dari ilmu sains (Martin et al., 2015).

Rendahnya tingkat keterampilan berpikir siswa ini ditunjukan juga dari temuan di lapangan. Suardana dan Selamet (2017) menyatakan rendahnya keterampilan berpikir kritis ditemukan pula pada siswa SMA di Kabupaten Buleleng, Provinsi Bali. Hasil penelitian menunjukkan bahwa skor rata-rata keterampilan berpikir kritis siswa SMA pada tingkat tinggi, menengah, dan tingkat rendah adalah 59,0 (kategori cukup), 43,1 (kategori rendah), dan 34,7 (kategori sangat rendah). Hal ini menunjukkan bahwa kualitas sumber daya manusia masih rendah. Diana et al. (2015) menemukan bahwa siswa kelas X MIPA 1 SMA N 5 Surakarta kurang mampu berpikir secara mendalam dalam membuat gagasan tanpa melihat buku atau catatan. Hasil tersebut mengindikasikan bahwa kemampuan berpikir kritis peserta didik rendah dan belum terlatihkan secara optimal. Didukung data prasiklus yang menunjukkan kemampuan menginterpretasi $59,17 \%$, menyimpulkan $58,33 \%$, mengevaluasi $35 \%$, menganalisis $55 \%$, menjelaskan $39,17 \%$, dan mengevaluasi konsep (pengaturan diri) $44,17 \%$. 
Salah satu faktor yang diduga menjadi penyebab rendahnya keterampilan berpikir kritis siswa adalah peran guru. Peran guru yang dapat memengaruhi keterampilan berpikir kritis siswa adalah ketidaktepatan guru memilih model pembelajaran di kelas. Model pembelajaran yang diterapkan oleh guru pada saat pembelajaran adalah model pembelajaran kooperatif tipe student team achievement division (STAD), namun dalam penerapannya belum sepenuhnya sesuai dengan sintaks model tersebut dan cenderung bersifat teacher centered yaitu semua informasi yang berkaitan dengan pembelajaran masih bersumber dari guru sehingga mengakibatkan siswa kurang aktif selama kegiatan belajar mengajar. Hal ini yang menyebabkan keterampilan berpikir kritis siswa kurang terlatih karena siswa cenderung menunggu intruksi dari guru daripada mengontruksi sendiri pengetahuannya. Pembelajaran yang baik adalah pembelajaran yang membiasakan siswa untuk berperan aktif dalam pembelajaran. Cara yang dapat ditempuh untuk membiasakan siswa berperan aktif dalam pembelajaran adalah dengan menghadapkan siswa dengan masalah. Masalah yang dimaksud bukanlah masalah well-structured melainkan masalah ill-structured atau open ended.

Redhana (2012) mengungkapkan bahwa pengajuan masalah ill-structured pada awal pembelajaran dapat membangkitkan keingintahuan siswa. Masalah ill-structured ini dapat bertindak sebagai starting point untuk memulai pembelajaran dan sebagai motivator bagi siswa untuk mempelajari materi IPA.

Salah satu model pembelajaran yang dapat melatihkan keterampilan berpikir kritis siswa adalah model pembelajaran berbasis masalah atau yang lebih dikenal dengan Problem Based Learning (PBL). Barrows (dalam Wardana, 2008), menyatakan bahwa PBL adalah model pembelajaran yang didasarkan pada prinsip bahwa masalah (problem) dapat digunakan sebagai titik awal untuk mendapatkan ataupun mengintegrasikan ilmu (knowledge) baru. Masalah digunakan sebagai sarana agar anak didik dapat belajar sesuatu yang dapat menyokong keilmuan.

Hasil penelitian Kono (2016) menunjukkan bahwa model PBL dapat melatih keterampilan berpikir kritis siswa dengan baik. Hasil Penelitian yang sejalan juga ditunjukkan oleh penelitian Yudhitya, et al. dan Hartati, et al. (2015), menjelaskan bahwa model PBL lebih efektif dalam meningkatkan keterampilan keterampilan berpikir kritis siswa.

Barrows (dalam Sadia, 2014) dalam tulisannya yang berjudul Problem Based Learning in Medicine and Beyond juga mengemukakan beberapa karakteristik PBL sebagai berikut, (1) proses pembelajaran bersifat student centered, (2) proses pembelajaran berlangsung dalam kelompok kecil, (3) guru berperan sebagai fasilitator atau pembimbing, (4) permasalahan-permasalahhan yang disajikan dalam setting pembelajaran diorganisasi dalam bentuk dan fokus tertentu dan merupakan stimulus pembelajaran, (5) nformasi baru diperoleh melalui belajar secara mandiri (self directed learning), dan (6) masalah merupakan wahana untuk mengembangkan keterampilan pemecahhan masalah.

Tahapan-tahapan model problem based learning menurut Sugiyanto (2010) terdiri dari lima fase yaitu, (1) orientasi siswa pada masalah aktual dan autentik, (2) mengorganisasi siswa untuk belajar, (3) membimbing penyelidikan individual/kelompok, (4) mengembangkan dan menyajikan hasil karya, dan (5) menganalisis dan mengevalusi proses pemecahan masalah.

Keunggulan model problem based learning diantaranya adalah sebagai berikut, (1) siswa didorong untuk memiliki keterampilan memecahkan masalahmasalah dalam situasi nyata, (2) siswa memiliki keterampilan membangun pengetahuannya sendiri melalui aktivitas belajar, (3) pembelajaran berfokus pada masalah sehingga materi yang tidak ada hubungannya tidak perlu dipelajari oleh siswa. Hal ini mengurangi beban siswa dengan menghafal atau menyimpan informasi, (4) terjadi aktivitas ilmiah pada siswa melalui kerja kelompok, (5) siswa 
terbiasa menggunakan sumber-sumber pengetahuan, baik dari perpustakaan, internet, wawancara, dan observasi, (6) siswa memiliki keterampilan menilai kemajuan belajarnya sendiri, (7) siswa memiliki keterampilan untuk melakukan komunikasi ilmiah dalam kegiatan diskusi atau presentasi hasil pekerjaan mereka, dan (8) kesulitan belajar siswa secara individual dapat diatasi melalui kerja kelompok dalam bentuk peer teaching Barrows (dalam Wardana, 2008). Model pembelajaran ini dipandang memiliki efektivitas yang besar dalam melatihkan dan mengembangkan keterampilan berpikir kritis siswa secara optimal.

Berdasarkan kajian teoritis tersebut, perlu dilakukan penelitian lebih lanjut tentang pengaruh model problem based learning terhadap keterampilan berpikir kritis siswa kelas VII SMP pada pembelajaran IPA.

\section{METODE}

Penelitian ini merupakan penelitian eksperimen semu dengan rancangan nonequivalent pretest-posttest control group design. Populasi dalam penelitian ini adalah seluruh siswa kelas VII semester genap tahun pelajaran 2017/2018 di SMP Negeri 6 Singaraja yang berjumlah 304 orang yang tersebar ke dalam 11 kelas. Pengambilan sampel dalam penelitian ini dilakukan dengan menggunakan teknik Cluster Random Sampling. Siswa kelas VIIB 3 sebagai kelas eksperimen yang diberikan perlakuan model problem based learning dan siswa kelas VIIB4 sebagai kelas kontrol yang diberikan perlakuan model pembelajaran kooperatif tipe STAD dengan jumlah masing-masing 25 orang. Objek dalam penelitian ini adalah keterampilan berpikir kritis siswa. Data keterampilan berpikir kritis siswa dikumpulkan menggunakan tes keterampilan berpikir kritis yang berjumlah enam soal uraian. Karakteristik tes dalam penelitian ini memiliki konsistensi internal butir 0,439 hingga 0,695, memiliki reliabilitas sebesar 0,775 , dan indeks kesukaran butir 0,31 sampai 0,70.

Data dianalisis secara deskriptif dan satistik inferensial. Data keterampilan berpikir kritis siswa pada kelompok eksperimen dan kelompok kontrol diuji menggunakan uji ANAKOVA satu jalur dengan taraf signifikansi 5\%. Sebelum dilaksanakan uji hipotesis, data yang diperoleh harus memenuhi beberapa asumsi, yakni uji normalitas, uji homogenitas, uji linearitas dan uji homogenitas kemiringan garis regresi, semua pengujian dibantu dengan program SPSS 17.0 for Windows.

\section{HASIL DAN PEMBAHASAN Hasil}

Nilai rata-rata pretest digunakan untuk mengukur keterampilan berpikir kritis awal siswa sedangkan nilai rata-rata posttest digunakan untuk mengukur keterampilan berpikir kritis akhir siswa. Grafik perbandingan nilai rata-rata pretest dan nilai rata-rata posttest disajikan pada Grafik 1.

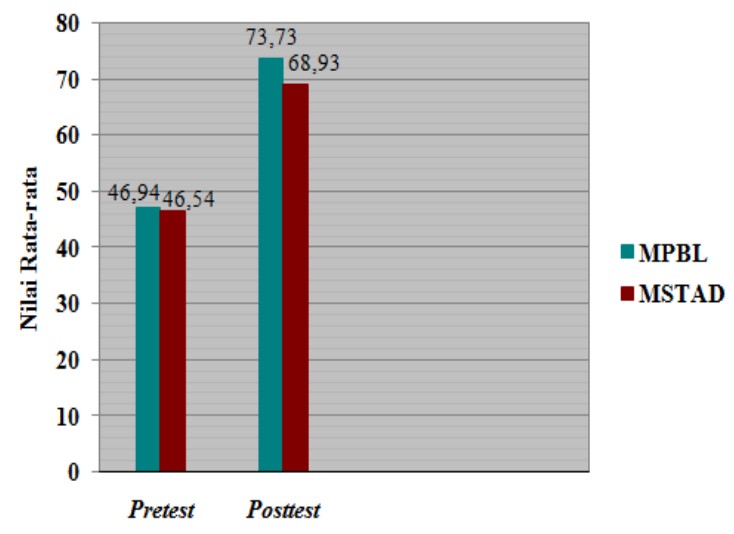

Gambar 1. Perbandingan Nilai Rata-Rata Pretest dan Nilai Rata-Rata Posttest

Berdasarkan Gambar 1. menunjukan bahwa nilai keterampilan berpikir kritis siswa pada masing-masing kelompok mengalami perubahan yang positif. Jika dilihat dari nilai pretest kelompok MPBL dan MSTAD memiliki nilai rata-rata yang hampir sama. Namun setelah diberikan perlakuan terhadap masing-masing kelompok nilai rata-rata kelompok MPBL memperoleh nilai rata-rata yang lebih tinggi dibandingkan dengan kelompok MSTAD.

Secara lebih rinci perbandingan nilai rata-rata setiap komponen keterampilan berpikir kritis kelompok MPBL dan kelompok MSTAD ditunjukkan pada Gambar 2. 


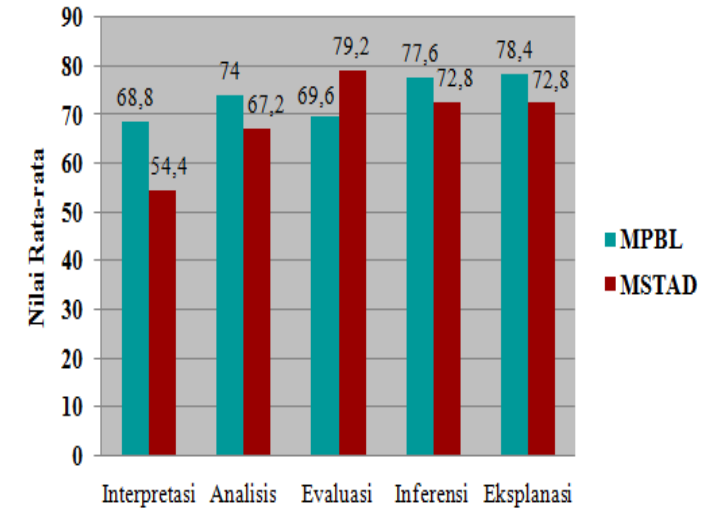

Gambar 2. Perbandingan Nilai Rata-rata Setiap Komponen Keterampilan Berpikir Kritis pada Masing-masing Kelompok

Berdasarkan Gambar 2. nilai ratarata setiap komponen keterampilan berpikir kritis pada kelompok MPBL memiliki nilai rata-rata lebih tinggi dibandingkan kelompok MTAD. Kelompok MPBL lebih baik pada empat komponen yaitu komponen interpretasi, analisis, inferensi dan eksplanasi. Namun pada komponen evaluasi, kelompok MPBL memeroleh nilai rata-rata yang lebih rendah dibandingkan kelompok MSTAD.

Sebelum uji hipotesis dilakukan uji asumsi. Hasil uji asumsi menunjukan semua sebaran data berdistribusi normal, varians antar kelompok homogen, hubungan antara variabel kovariat dan variabel terikat linier, dan tidak ada interaksi antara variabel kovariat dan variabel bebas. Jadi, uji ANAKOVA satu jalur dapat dilanjutkan. Adapun hasil uji hipotesis yang diperoleh disajikan pada Tabel 1.

Tabel 1. Hasil Uji Hipotesis

\begin{tabular}{lccccc}
\hline \multicolumn{1}{c}{ Source } & $\begin{array}{c}\text { Type III Sum of } \\
\text { Squares }\end{array}$ & $d f$ & Mean Square & $F$ & Sig. \\
\hline Corrected Model & $1282,865^{\mathrm{a}}$ & 2 & 641,433 & 10,715 & 0,000 \\
Intercept & 9292,395 & 1 & 9292,395 & 155,224 & 0,000 \\
Keterampilan berpikir kritis & 999,645 & 1 & 999,645 & 16,698 & 0,000 \\
Awal & 265,914 & 1 & 265,914 & 4,442 & 0,040 \\
Model Pembelajaran & 2813,635 & 47 & 59,865 & & \\
Error & 255437,000 & 50 & & & \\
Total & 4096,500 & 49 & & & \\
Corrected Total & & & & & \\
\hline
\end{tabular}

Berdasarkan Tabel 1, angka signifikansi pada lajur model pembelajaran menunjukan angka signifikansi sebesar 0,040 . Angka signifikansi tersebut lebih kecil dari 0,05 , sehingga dapat diambil keputusan $\mathrm{H}_{0}$ ditolak dan dapat disimpulkan bahwa terdapat perbedaan pengaruh model pembelajaran PBL dengan model pembelajaran kooperatif tipe STAD terhadap keterampilan berpikir kritis siswa pada pembelajaran IPA.

\section{Pembahasan}

Hasil analisis menyatakan bahwa keterampilan berpikir kritis siswa yang diberikan perlakuan model PBL lebih tinggi dibandingkan dengan keterampilan berpikir kritis siswa yang diberikan perlakuan model pembelajaran kooperatif tipe STAD.

Keterampilan berpikir kritis awal siswa yang diukur menggunakan pretest merupakan variabel kovariat. Nilai ratarata pretest kelompok MPBL dan kelompok MSTAD menunjukan nilai ratarata yang hampir sama, yaitu 46,93 dan 46,53. Berdasarkan hasil tersebut maka nilai rata-rata pretest dapat dikendalikan dalam penelitian ini sehingga tidak memengaruhi keterampilan berpikir kritis siswa. Hal tersebut dipertegas oleh uji interaksi, pada pengaruh interaktif antara keterampilan berpikir kritis awal dan model pembelajaran tampak angka signifikansi yang lebih besar dari 0,05 . Hal ini berarti tidak terdapat interaksi antara keterampilan berpikir kritis awal dengan 
model pembelajaran terhadap keterampilan berpikir kritis akhir siswa. Berdasarkan hasil analisis terebut, keterampilan berpikir kritis akhir siswa hanya dipengaruhi oleh model pembelajaran setelah dilakukan pengendalian terhadap variabel kovariat. Variabel kovariat berfungsi sebagai kontrol terhadap semua perlakuan yang tidak terkontrol terhadap variabel terikat. Trochim (2006) menyatakan variabel kovariat adalah variabel yang digunakan untuk menghilangkan atau mengurangi noise pada analisis data yang disebabkan oleh variabel lain selain variabel yang diteliti sehingga efek dari variabel yang diteliti dapat terlihat lebih jelas. Setelah diberikan perlakuan, nilai rata-rata posttest kelompok MPBL lebih tinggi dibandingkan dengan kelompok MSTAD, yaitu 73,73 pada kelompok MPBL dan 68,93 pada kelompok MSTAD. Hal tersebut menunjukan model PBL lebih efektif dalam melatihkan dan mengembangkan keterampilan berpikir kritis siswa dibandingkan dengan model kooperatif tipe STAD.

Hasil penelitian ini juga didukung oleh penelitian yang dilakukan oleh Hartati (2015), dalam penelitiannya ditemukan bahwa keterampilan berpikir kritis siswa pada kelas eksperimen setelah diberikan perlakuan model PBL mengalami peningkatan yang cukup baik. Penelitian Astika (2013) menyatakan bahwa terdapat perbedaan sikap ilmiah dan keterampilan berpikir kritis antara siswa yang belajar model PBL dengan siswa yang belajar model pembelajaran ekspositori. Sikap ilmiah dan keterampilan berpikir kritis siswa yang belajar menggunakan model PBL lebih baik daripada siswa yang belajar menggunakan model pembelajaran ekspositori.

Perbedaan keterampilan berpikir kritis siswa pada kelompok MPBL dan kelompok MSTAD disebabkan karena pada model PBL siswa terlebih dahulu diberikan permasalahan dunia nyata yang bersifat ill-structured tanpa adanya bimbingan dari guru. Siswa dituntut mencari dan mengontruksi sendiri materi pelajaran yang terkait dengan permasalahan serta akan mengembangkan kemampuannya dalam berpikir. Berkaitan dengan hal ini, Redhana (2012) mengungkapkan bahwa pengajuan masalah ill-structured pada awal pembelajaran dapat membangkitkan keingintahuan siswa. Masalah illstructured ini dapat bertindak sebagai starting point untuk memulai pembelajaran dan sebagai motivator bagi siswa untuk mempelajari materi IPA. Kono (2016) mengungkapkan bahwa model PBL menitik beratkan pada kemandirian siswa dalam mengeksplorasi pengetahuan mereka saat memecahkan masalah yang telah dirumuskan sehingga siswa dapat menemukan sendiri jawaban dari setiap permasalahannya. Berbeda halnya pada model pembelajaran kooperatif tipe STAD, siswa terlebih dahulu diajarkan materi oleh guru. Guru menyajikan materi di depan kelas secara ceramah yang difokuskan pada konsep-konsep materi yang akan dibahas, setelah itu siswa hanya berfokus pada diskusi kelompok sehingga siswa yang memiliki kemampuan kurang dalam berdiskusi dan malu bertanya kurang terbiasa menggunakan keterampilan berpikirnya.

Berdasarkan tahapan kegiatan model PBL, pada kegiatan menganalisis masalah, siswa diberikan LKS yang berisi permasalahan yang telah dirancang untuk diselesaikan. Pada kegiatan ini, siswa didorong untuk bisa merumuskan masalah, mengidentifikasi masalah, menemukan informasi dari masalah yang diberikan, menyusun hipotesis dan mencoba merancang penyelesaian masalah yang diberikan. Pemberian masalah di awal pembelajaran akan memotivasi siswa untuk belajar. Sesuai dengan pendapat dari Jumaisyaroh (2014) yang menyatakan bahwa melalui pemberian masalah pada awal pembelajaran akan mendorong siswa untuk dapat menyelesaikan permasalahan yang diberikan melalui kegiatan menganalisis, mengkritik, dan menarik kesimpulan dari permasalahan tersebut sehingga dapat melatih keterampilan berpikir kritis siswa. Hal ini sejalan dengan teori belajar penemuan Bruner terutama dalil penemuan dan dalil pengaitan. Metode penemuan memang merupakan 
konsep yang mendasari model PBL karena dalam model PBL siswa diberikan masalah untuk ditemukan cara penyelesaiannya oleh siswa dan penemuannya tersebut merupakan pengetahuan yang berkaitan dengan pengetahuan dari materi yang akan diajarkan. Dalil pengaitan juga mendasari model PBL karena dalam pembelajaran ini setiap konsep berkaitan dengan konsep lainnya (Sunaryo, 2014).

Kegiatan melaksanakan percobaan terhadap rancangan penyelesaian masalah yang telah dibuat. Pada kegiatan ini siswa di dalam kelompoknya sudah mendapatkan LKS, kemudian siswa akan berdiskusi dengan teman sekelompoknya untuk merencanakan solusi penyelesaian masalah yang terdapat pada LKS. Peran guru hanya memberikan bantuan atau scaffolding secara tidak langsung berupa petunjuk, pertanyaan atau informasi yang dapat membantu siswa yang berkaitan dengan materi pembelajaran. Salah satu karateristik pembelajaran PBL dalam penelitian ini yaitu siswa diberi kebebasan untuk mencari dan menemukan sendiri alternatif penyelesaian masalah autentik yang dikerjakan. Hal ini sejalan dengan pendapat yang dikemukakan oleh Tenggarudin (2016), adanya kebebasan berpikir dalam menyelesaikan masalah autentik oleh siswa merupakan peluang untuk mengasimilasi pengetahuan yang dimiliki sebelumnya sehingga dapat meningkatkan keterampilan berpikir kritis siswa.

Kegiatan menyampaikan solusi yang diberikan untuk menyelesaikan masalah serta hasil dari penyelesaian masalah tersebut. Pada kegiatan ini kelompok lain bisa memberikan tanggapan kepada kelompok yang presentasi, sehingga terjadi proses diskusi untuk mendapatkan hasil yang benar. Tahap pembentukan keterampilan berpikir kritis terjadi pada saat siswa membandingkan hasil pekerjaan kelompoknya dengan hasil kerja kelompok lain dan pada saat siswa mengajukan pertanyaan kepada kelompok penyaji. Jadi, siswa tidak menerima informasi dari orang lain begitu saja. Vygotsky percaya bahwa pengetahuan tidak bisa ditransfer dari pikiran orang lain ke pikiran seseorang, melainkan orang tersebut yang harus membangun sendiri pengetahuannya melalui interaksi dengan orang lain (Sunaryo, 2014).

Di lain pihak, nilai rata-rata keterampilan berpikir kritis pada kelompok siswa yang diberi perlakuan model pembelajaran kooperatif tipe STAD lebih rendah daripada kelompok siswa yang diberi perlakuan model PBL. Hal ini dikarenakan pada model pembelajaran kooperatif tipe STAD siswa tidak diarahkan untuk merancang sendiri solusi penyelesaian masalah yang dihadapinya, siswa langsung mendiskusikan penyelesaian masalah yang terdapat di LKS secara berkelompok. Proses pembelajaran yang demikian kurang efektif, karena siswa tidak diberi kesempatan untuk mengidentifikasi masalah dan menyusun solusi penyelesaian masalah yang dihadapinya. Siswa mengerjakan LKS sesuai dengan rancangan yang telah disediakan pada LKS. Hal ini menyebabkan siswa malas berpikir sehingga kegiatan diskusi akan berlangsung lama karena siswa kurang paham mengenai rancangan solusi yang terdapat pada LKS sehingga guru harus menjelaskan kembali maksud dari LKS. Selain itu, siswa yang malas cenderung hanya memanfaatkan teman sekelompoknya untuk mengerjakan LKS sehingga kontribusi seluruh siswa dalam proses pembelajaran tidak berlangsung optimal. Hal ini sejalan dengan pernyataan yang dikemukakan oleh Miftahul dalam Hidayat (2013) yang menyatakan bahwa salah satu kendala dari pembelajaran kooperatif adalah munculnya free rider atau pengendara bebas, yang dimaksud free rider adalah beberapa siswa yang tidak bertanggung jawab secara personal pada tugas kelompoknya. Mereka hanya mengekor saja apa yang dilakukan oleh teman-teman satu kelompoknya. Selain itu, pembelajaran dengan model pembelajaran kooperatif tipe STAD tidak terdapat kegiatan yang mampu melatihkan keterampilan berpikir kritis siswa sehingga siswa tidak mampu merefleksikan solusi yang telah digunakan dalam menyelesaikan masalah yang dihadapinya. Berdasarkan pemaparan 
sebelumnya, model PBL mampu melatihkan keterampilan berpikir kritis siswa lebih baik dibandingkan dengan model pembelajaran kooperatif tipe STAD.

Model PBL dinyatakan lebih baik dalam melatihkan keterampilan berpikir kritis siswa dibandingkan dengan model pembelajaran kooperatif tipe STAD juga dilihat dari nilai rata-rata setiap komponen keterampilan berpikir kritis. Nilai rata-rata setiap komponen keterampilan berpikir kritis kelompok MPBL lebih tinggi dibandingkan kelompok MSTAD, kelompok MPBL lebih baik pada empat komponen yaitu komponen interpretasi, analisis, inferensi, dan eksplanasi. Namun pada komponen evaluasi, kelompok MPBL memperoleh nilai rata-rata yang lebih rendah dibandingkan kelompok MSTAD.

Nilai rata-rata komponen interpretasi yang diperoleh kelompok MPBL lebih tinggi daripada kelompok MSTAD karena pada kelompok MPBL, pada saat siswa diberikan masalah siswa dituntut untuk merancang sendiri solusi penyelesaian masalah yang dihadapinya, siswa dibiasakan untuk menafsirkan solusi-solusi yang dapat digunakan menyelesaikan masalah yang terdapat di LKS.

Nilai rata-rata komponen analisis yang diperoleh kelompok MPBL lebih tinggi dibandingkan dengan kelompok MSTAD karena pada proses pembelajaran dengan model PBL, siswa diberikan rangsangan berupa masalah-masalah yang membutuhkan kemampuan analisis siswa, sehingga siswa terbiasa menganalisis suatu permasalahan.

Nilai rata-rata yang diperoleh kelompok MPBL pada komponen evaluasi lebih rendah dibandingkan dengan kelompok MSTAD. Rendahnya komponen evaluasi pada kelompok MPBL disebabkan kurangnya waktu latihan yang diberikan kepada siswa untuk membahas soal yang hampir sama dengan soal-soal pada saat tes, siswa memerlukan latihan berulang-ulang mengatasi masalah tersebut dan juga untuk membiasakan siswa berpikir secara kritis. Faktor lain yang dapat berpengaruh yaitu memerlukan perencanaan yang matang dalam menerapkan model PBL dalam pembelajaran, agar hasil yang diperoleh lebih optimal.

Nilai rata-rata yang diperoleh kelompok MPBL pada komponen menyimpulkan (inferensi) lebih tinggi dibandingkan pada kelompok MSTAD. Perbedaan nilai rata-rata ini menunjukan bahwa siswa di kelompok MSTAD kurang dalam hal mengidentifikasi dan memilih elemen yang dibutuhkan untuk menyusun simpulan yang memiliki alasan, untuk menduga dan menegakkan diagnosis, serta untuk memutuskan konsekuensi yang harus diambil dari data, informasi, pernyataan, kejadian prinsip, opini, konsep.

Nilai yang diperoleh kelompok MPBL pada komponen eksplanasi lebih tinggi dibandingkan dengan kelompok MSTAD. Dilihat dari nilai rata kelompok MPBL yang lebih besar dari MSTAD, mengindikasikan siswa pada kelompok MPBL lebih baik dalam kemampuan menyampaikan hasil, menjelaskan prosedur, dan mempresentasikan argumen siswa.

Keunggulan model PBL juga ditunjang oleh aktivitas belajar siswa selama proses pembelajaran di kelas. Aktivitas belajar siswa yang dibelajarkan menggunakan model PBL lebih baik daripada aktivitas belajar siswa yang dibelajarkan menggunakan model pembelajaran kooperatif tipe STAD.

Hasil penelitian ini belum tercapai secara maksimal karena terdapat kendala dalam proses pembelajaran di kelas. Adapun beberapa kendala yang dialami dalam penelitian ini, beserta cara yang telah ditempuh untuk menanggulanginya dipaparkan sebagai berikut. Pertama, siswa pada kelompok MPBL belum terbiasa belajar dengan metode diskusi karena biasanya siswa hanya mendapat informasi dari guru melalui metode ceramah, dimana siswa menerima informasi secara penuh. Kendala ini diatasi dengan menuntun dan membimbing siswa secara intensif agar siswa terbiasa belajar dengan menggunakan metode diskusi. Kedua, siswa pada kelompok MPBL maupun MSTAD belum terbiasa melaksanakan kegiatan praktikum secara mandiri. Pada saat melakukan kegiatan praktikum 
banyak siswa yang masih kebingungan apa yang harus dikerjakan. Akibatnya, waktu untuk melaksanakan praktikum banyak terbuang. Antisipasi terhadap permasalahan, penulis memberikan tuntunan kepada siswa sehingga kegiatan praktikum dapat berjalan dengan optimal. Ketiga, pelaksanaan praktikum dan kegiatan diskusi pada masing-masing kelompok masih didominasi oleh beberapa orang siswa saja dan beberapa siswa lain hanya diam. Akibatnya sedikit siswa yang mengerti makna pembelajaran tersebut. Antisipasi untuk permasalahan ini, peneliti memberikan penilaian secara individu yang menyangkut seluruh komponen belajar siswa selama kegiatan pembelajaran. Keempat, siswa belum terbiasa dengan kegiatan presentasi di kelas, sehingga ketika guru memberikan kesempatan pada salah satu kelompok untuk melakukan presentasi terhadap hasil yang diperoleh, siswa masih belum menunjukan inisiatif sendiri untuk mempresentasikan hasil kelompoknya dan saling menunggu sehingga waktu pembelajaran banyak terpotong. Permasalahan ini diatasi dengan menunjuk secara langsung salah satu kelompok untuk mempresentasikan hasil diskusi praktikumnya dan menunjuk kelompok lain untuk memberikan perbandingan. Kelima, siswa tidak terbiasa mengerjakan LKS yang menuntut keterampilan berpikir kritis sehingga siswa sering mengalami kesulitan dalam menentukan solusi yang tepat untuk menyelesaikan masalah yang terdapat pada LKS. Kendala ini diminimalisir dengan mengarahkan siswa agar terbiasa membaca petunjuk pengerjaan LKS terlebih dahulu agar pengerjaan LKS lebih terstruktur. Keenam, ketersediaan bahan ajar yang mendukung proses pembelajaran belum cukup. Buku adalah sumber daftar pustaka yang digunakan siswa untuk menggali informasi yang terkait dengan materi pembelajaran di kelas. Jika sumber daftar pustaka yang dimiliki oleh siswa terbatas maka proses pembelajaran tidak dapat berlangsung dengan optimal. Kendala ini berusaha diminimalisir dalam penelitian ini dengan cara menyediakan sumber-sumber yang relevan dengan materi pembelajaran.

\section{SIMPULAN DAN SARAN}

Berdasarkan hasil penelitian dan pembahasan dapat dibuat simpulan bahwa terdapat perbedaan keterampilan berpikir kritis siswa kelas VII antara kelompok siswa yang diberikan perlakuan model PBL dengan kelompok siswa yang diberikan perlakuan model pembelajaran kooperatif tipe STAD. Keterampilan berpikir kritis kelompok siswa yang dibelajarkan dengan model PBL lebih baik dibandingan keterampilan berpikir kritis siswa yang dibelajarkan dengan model pembelajaran kooperatif tipe STAD. Terlihat dari rata-rata nilai posttest kelas eksperimen sebesar 73,33 lebih tinggi daripada rata-rata nilai posttest kelas kontrol sebesar 68,93.

Berdasarkan hasil penelitian ini, maka dapat diajukan beberapa saran sebagai berikut. (1) Guru (khususnya guru IPA) disarankan untuk menerapkan model PBL dalam pembelajaran di kelas karena model PBL mampu melatihkan keterampilan berpikir kritis siswa, agar penerapan model PBL dapat berpengaruh dengan optimal, maka guru harus merancang problem yang benar-benar mampu merangsang daya nalar, keterampilan berpikir, dan kemampuan pemecahan masalah siswa. Selain itu, problem yang dirancang hendaknya berkaitan dengan kehidupan sehai-hari siswa. Guru juga diharapkan untuk lebih memperhatikan komponen keterampilan berpikir kritis, terutama pada komponen yang ditemukan masih rendah, yaitu komponen interpretasi dan evaluasi. Penerapan model PBL dalam pembelajaran dapat dilakukan lebih maksimal dengan menekankan latihan dalam mengerjakan soal, dengan pemberian latihan secara intensif akan membantu siswa untuk mengembangkan keterampilan berpikir kritis dan keterampilan mengatasi masalah. (2) sekolah diharapkan melengkapi sarana dan prasarana yang belum terpenuhi untuk menunjang proses pembelajaran agar menjadi lebih bermakna, dan (3) peneliti lain diharapkan melakukan 
penelitian lebih lanjut tentang upaya peningkatan keterampilan berpikir kritis siswa dengan pemilihan materi yang berbeda, alokasi waktu yang lebih lama, jumlah sampel lebih banyak, dan desain penelitian yang lebih tepat sehingga hasil penelitian dapat tercapai dengan baik.

\section{DAFTAR PUSTAKA}

Apriyani, N. H. 2013. Pengaruh Penggunaan Media Kartu Bergambar Melalui Model Pembelajaran Kooperatif Tipe Number Head Together (NHT) Terhadap Keterampilan Berpikir Kritis Pada Materi Pokok Protista. Skripsi: Universitas Lampung, Bandar Lampung.

Astika, K U, I K Suma, I W Suastra. 2013. Pengaruh Model Pembelajaran Berbasis Masalah Terhadap Sikap IImiah dan Keterampilan Berpikir Kritis. e-Journal Program Pascasarjana Universitas Pendidikan Ganesha, 3 tahun 2013. Tersedia pada http://pasca.undiksha.ac.id/ejournal/i ndex.php/jurnal_ipa/article/view/81 (diakses pada tanggal 15 November 2017).

Candiasa, I M. 2011. Statistik Multivariat Disertai Aplikasi SPPS. Singaraja: Unit Penerbitan Universitas Pendidikan Ganesha.

Dewi, N. Riandi. 2016. Analisis Kemampuan Berpikir Kompleks Siswa Melalui Pembelajaran Berbasis Masalah Berbantuan Mind Mapping. EDUSAINS, 8 (1), 2016, 98-107. Tersedia pada http://journal.uinjkt.ac.id/index.php/e dusains/article/view/1805 (diakses pada tanggal 08 Juli 2018)

Dewi, S.R, I Made Citra Wibawa, Ni Luh Pande Latria Devi. 2017. Kemampuan Berpikir Kritis Dan Keterampilan Proses Dalam Pembelajaran Siklus Belajar 7e Berbasis Kearifan Lokal. 6(1). Tersedia pada https://ejournal.undiksha.ac.id/index. php/JPI/article/view/9476 (diakses pada tanggal 8 januari 2018).
Diana, N. Puguh Karyanto, Suciati, Indriyati. 2015. Penerapan E-Module Berbasis Problem Based Learning untuk Meningkatkan Kemampuan Berpikir Kritis dan Mengurangi Miskonsepsi pada Materi Ekologi Siswa Kelas X MIPA 1 SMA Negeri 5 Surakarta Tahun Pelajaran 2014/2015. Biologi, Sains, Lingkungan, dan Pembelajarannya. SP-005-2. Tersedia pada https://media.neliti.com/media/public ations/176152-ID-none.pdf (diakses pada tanggal 08 Juli 2018).

Hartati, R, Hayat Solihin. (2015). Meningkatkan Keterampilan Berpikir Kritis Siswa Melalui Implementasi Model Problem Based Learning (PBL) Pada Pembelajaran IPA Terpadu Siswa SMP. Prosiding Simposium Nasional Inovasi dan Pembelajaran Sains 2015 (SNIPS 2015). Tersedia pada http://www.academia.edu/29127135 (diakses pada tanggal 20 Desember 2017).

Kementrian Pendidikan dan Kebudayaan. 2014. IImu pengetahuan alam SMP/MTs Kelas VII Semester 2 edisi revisi. Jakarta: Kementerian Pendidikan dan Kebudayaan.

Kono, R. 2016. Pengaruh Model Problem Based Learning (PBL) Terhadap Pemahaman Konsep Biologi Dan Keterampilan Berpikir Kritis Siswa Tentang Ekosistem Dan Lingkungan Di Kelas X SMA Negeri 1 Sigi. Mahasiswa Program Studi Magister Pendidikan Sains Pascasarjana Universitas Tadulako, Dosen Program Studi Magister Pendidikan Sains Pascasarjana Universitas Tadulako. Jurnal Sains dan Teknologi Tadulako, 5(1), hlm 28-38. Tersedia pada http://jurnal.untad.ac.id/jurnal/index.p $\mathrm{hp} / \mathrm{JSTT} /$ article/download/6958/5595 (diakses pada tanggal 15 Desember 2017).

Litbang Kemendikbud. 2015. Survei International Programme for International Student Assessment (PISA). Tersedia pada http://litbang.kemdikbud.go.id/index. 
php/survei-internasional-pisa

(diakses pada tanggal 17 Desember 2017)

Martin, O. M, Ina V. S. Mullis, Pieree Foy, Martin Hooper. 2015. International Results in Science. Tersedia pada http : // timssandpirls . bc . edu / timss2015 / international -results / wp -content / uploads / filebase / full\%20pdfs / T15 -International Results - in -Science - Grade - 8 . pdf (diakses pada tanggal 1 Juli 2018).

Oktiningrum, W. 2014. Evaluasi Ujian Nasional (UN), PISA dan TIMSS. Jakarta: Sampoerna Foundation. http://news.detik.com/read/2013/12/1 2/010409/2439467/158/1/mendikbud -survei-pisa-makin-memperkuatpentingnya-kurikulum-2013 (diunduh tanggal 06 Juni 2018).

Peraturan Menteri Pendidikan dan Kebudayaan No. 22 Tahun 2016 tentang Standar Proses Pendidikan Dasar dan Menengah.

Peraturan Menteri Pendidikan Nasional No. 20 Tahun 2016 tentang Standar Kompetensi Lulusan untuk Satuan Pendidikan Dasar dan Menengah.

Redhana, I W. 2012. Model Pembelajaran Berbasis Masalah dan Pertanyaan Socratik Untuk Meningkatkan Keterampilan Berpikir Kritis Siswa. FMIPA Universitas Pendidikan Ganesha. Cakrawala Pendidikan, november 2012, th. XXXI, no. 3. Tersedia pada https://journal.uny.ac.id/index.php/cp /article/view/1136 (diakses pada tanggal 17 Desember 2017).

Redhana, I W. 2010. Pengaruh Model Pembelajaran Berbasis Peta Argumen terhadap Keterampilan Berpikir Kritis Siswa pada Topik Laju Reaksi. Jurnal Pendidikan dan Pengajaran, 43(2): 141-148. Tersedia pada https://ejournal.undiksha.ac.id/index. php/JPP/article/view/1721 (diakses pada tanggal 20 Desember 2017).

Suardana, I. N, I Nyoman Selamet. 2012. Analisis Keterampilan Berpikir Kritis Siswa SMA Di Kabupaten Buleleng. Prosiding Seminar Nasional MIPA.
Tersedia pada https://ejournal.undiksha.ac.id/index. $\mathrm{php} / \mathrm{semnasmipa/article/view/2800}$ (diakses pada tanggal 20 Desember 2017).

Tenggarudin. 2016. Strategi Pelatihan Guru dan Siswa Model Pembelajaran Problem Based Learning (PBL) Terintegrasi Lesson Study untuk Melatihkan Kemampuan Berpikir Kritis pada Pembelajaran Biologi. Proceeding Biology Education Conference, (ISSN: 25285742), Vol 13(1) 2016: 381-387. Tersedia pada https://media.neliti.com/media/public ations/173827-ID-strategi-pelatihanguru-dan-siswa-model.pdf. (diakses pada tanggal 14 Juni 2018)

Trochim, W M. K, Donnelly J P. 2006. The Research Methods Knowledge Base. Third Edition. Connel University.

Ullynuha, L. 2015. Pengaruh Pembelajaran Problem Based Learning (PBL) Terhadap Kemampuan Berpikir Kritis Siswa Kelas X SMA Negeri 6 Surakarta Tahun Pelajaran 2012/2013. Jurnal Pendidikan Biologi, Vol 7 No 1. Tersedia pada https://media.neliti.com/media/public ations/118169-ID-none.pdf. (diakses pada tanggal 29 Juni 2018).

Undang-Undang Republik Indonesia No. 20 Tahun 2003 tentang Sistem Pendidikan Nasional.

Yudhitya, L, Tri Jalmo, Rini Rita Marpaung. 2015. Pengaruh Model PBL Terhadap Keterampilan Berpikir Kritis Dan Aktivitas Belajar Siswa. Jurnal Bioterdidik, 3 (9) (2015). Tersedia pada http://jurnal.fkip.unila.ac.id/index.php IJBT/article/view/9731 (diakses pada tanggal 17 Desember 2017).

Zubaidah, S.2015. Assesmen Berpikir Kritis Terintegrasi Tes Essay. Proceeding Symposium on Biology Education hal 200 ISBN: 978-60272412-0-6. 